\title{
PERSPECTIVES
}

\section{Phytobiomes Contribute to Climate Processes that Regulate Temperature, Wind, Cloud Cover, and Precipitation}

\author{
Cindy E. Morris, ${ }^{\dagger}$ Plant Pathology Research Unit, INRA, PACA Research Center, 84143 Montfavet, France \\ Accepted for publication 15 April 2018.
}

\section{ABSTRACT}

In the management of plant health, climate and weather can be perceived as variables of the abiotic environment to which plants, and their associated biota, are passively subjected. However, research on Earth systems is now revealing how weather and climate can be markedly influenced by land use and by the types and extent of vegetation in particular. Plant-associated biota can alter the properties of vegetation that underlie the mechanisms by which it influences weather and climate. Therefore, it is important to consider the extent to which phytobiomes could impact climate and weather and the potential consequences for plant health and production and for processes that possibly exacerbate or modulate climate change. This commentary will illustrate how the exchange

of mass and energy between the atmosphere and land cover modulates temperature, winds, cloud formation and precipitation at local, regional and even greater scales and the role of plants and their associated biota in these effects. Via these exchanges, phytobiomes contribute to the climatic and weather variations to which they are in turn subjected. This argues for an expanded perspective of phytobiomes that considers their role in Earth system processes and that integrates knowledge of landatmosphere feedbacks into the management practices of crops and other vegetation. This knowledge will contribute to a vision of how management of the biophysical setting of crop cultivation could leverage environmental conditions locally and regionally.
\end{abstract}

The Phytobiomes Initiative contributes to rejuvenating fundamental concepts of agricultural ecology and the efficient production of food, fiber, feed and fuel by capitalizing on knowledge about the interactions of plants with their associated biota and their interdependence with abiotic parameters. This initiative also harkens back to the Disease Triangle that describes plant health as the outcome of interactions of the plant with biotic and abiotic components of the environment but with an expanded perspective on the biotic elements of the system. Biomes, in general, are a particular assemblage of flora and fauna in a certain type of environment. Earth's biomes, for example, are classified according to abiotic traits such as rainfall and temperature and their influence on the associated living organisms, plants in particular. In this light, it is reasonable to expect that abiotic environmental parameters are part of the description of any particular phytobiome. At present, perspectives on plant health and plant production usually consider that most abiotic conditions, and in particular the weather and climate that characterize a given habitat, are variables to which plants are passively subjected. However, research on Earth systems is now revealing the dependence of weather and climate on land use and, in particular, on vegetation.

The impacts of plants on the physical environment have always been readily apparent in the shading effects of plant canopies that alter

${ }^{\dagger}$ Corresponding author: C. E. Morris; E-mail: cindy.morris@inra.fr

cc) (i) (s) $\ominus$ Copyright (C) 2018 The Author(s). This is an open access article distributed under the CC BY-NC-ND 4.0 International license. temperature, relative humidity, wind speed and turbulence under canopies. But recently, there is increasing evidence that plants have more extensive impacts on the environment at the scale of watersheds and across continents that influence climate, weather and the water cycle. These large-scale influences are being intensively investigated because of the feedback cycles they set-off (Mahmood et al. 2014; McAlpine et al. 2009) that are suspected to lead to droughts, landslides and other disasters in extreme cases. But these investigations are mostly from the perspective of changing land cover due to deforestation/reforestation, urbanization, monoculture, etc. At present, there are very few studies of how the specific components of phytobiomes-beyond the plant itself-directly participate in these feedbacks. However, it is well known that the biota associated with plants can affect leaf area, the density of plant stands, rates of photosynthesis and evapotranspiration, etc., namely the properties of land cover that have consequences on climate, weather and the water cycle. Therefore, there is little intellectual risk in suspecting that phytobiomes as a whole have a role in the interactions between land cover and the atmosphere that influence the conditions of the physical environment in which the dynamics between plants and their biota are played out. Feedbacks between the phytobiome and climate and weather would likely have consequences for plant health and production because temperature and water availability in particular reign many aspects of plant development and defense reactions and the dynamics of invertebrate and microbial life cycles. Likewise, these feedbacks could also exacerbate the reactions of ecosystems to climate change as well as provide opportunities for mitigation of some 
negative effects of climate change. Therefore, it is time to bring to the attention of biologists in particular the feedbacks between vegetation and the atmosphere that alter the physical environment. The objectives of this article are to illustrate the main impacts that phytobiomes can have on climate, weather, and the water cycle, to explain the underlying mechanisms, and to thereby provide a springboard for setting future research challenges.

Land-atmosphere feedbacks result from exchanges of mass and energy between the atmosphere and land cover (Fig. 1). Land surfaces receive energy in the form of sunlight and as thermal infrared radiation (IR) as part of the greenhouse effect. IR is absorbed and re-emitted by the local environment. Sunlight is either directly reflected depending on surface albedo or is absorbed and then converted to sensible heat or latent heat after interacting with land cover and land surface features (Box 1). The exchange of mass between land cover and the atmosphere involves the uptake of $\mathrm{CO}_{2}$ and water (as condensation or precipitation) by plants and, in turn, the emission of water vapor into the atmosphere via transpiration, of $\mathrm{O}_{2}$ and volatile organic compounds. Primary biological aerosols, mostly in the form of intact plant-associated microorganisms and pollen, are released from plants and are also deposited on plants via aerial dissemination and deposition. The rates and intensities of these exchanges influence climate variables within the planetary boundary layer including air temperature, relative humidity, wind speed and turbulence, convective cloud development and precipitation at various scales (Mahmood et al. 2014). The scale of impact refers to the distance across which the effects ramify. These scales are classified as the microscale $\left(10^{-2}\right.$ to $\left.10^{3} \mathrm{~m}\right)$, the local scale $\left(10^{2}\right.$ to $\left.5 \times 10^{4} \mathrm{~m}\right)$, the meso-scale $\left(10^{4}\right.$ to $2 \times$ $\left.10^{5} \mathrm{~m}\right)$, and the macro-scale $\left(10^{5}\right.$ to $\left.10^{8} \mathrm{~m}\right)$ (Oke 1987).

Microscale effects of plant canopies on climate are well known and have been extensively considered in studies of disease epidemiology and insect pest dynamics (Tivoli et al. 2013). Assessment of plant canopy microclimates has progressed considerably as illustrated in the fine scale measurements of microclimate heterogeneity, such as temperature gradients across leaves and throughout plant canopies, that are now part of new technologies for precision agriculture to control pests and diseases (Faye et al. 2016). In contrast, effects on climate at larger scales are less obvious to observe directly and have generally not inspired any agronomic practices to modulate them (Bright et al. 2015). This commentary will focus on emblematic examples from the growing body of literature on land-atmosphere feedbacks to illustrate the mechanisms involved, the types of climatic phenomena that can be affected, and the scales of impact.

The larger-scale effects of land cover on climate and weather have been revealed in studies of the consequences of land use change. Major land cover changes on Earth have occurred via deforestation and conversion to agriculture, urbanization, and suburbanization and are part of the key features of the Anthropocene (Monastersky 2015). In 1700, wild or seminatural biomes constituted about $95 \%$ of the ice-free surface of the Earth, representing over $10^{8} \mathrm{~km}^{2}$ of the vegetated biomes (woodlands, savanna, grasslands, steppe, shrub lands, and tundra). Anthropogenic biomes have expanded to now constitute $50 \%$ of terrestrial land cover with $80 \%$ of these corresponding to crops, rangelands, and pastures (Ellis et al. 2010). As summarized in the overview by Mahmood and colleagues (Mahmood et al. 2014), conversion of grasslands to grazed and/or irrigated pastures has also occurred on a massive scale. Since about 1700,12 million $\mathrm{km}^{2}$ of woodlands have been converted to agriculture and have contributed to the fact that $11 \%$ of global land area is currently farmed. In addition, over $20 \%$ of global land area is grazed by livestock. These significant and ongoing changes have revealed how land use impacts temperature, winds, cloud formation and precipitation at local and meso-scales and, in some cases, at macro-scales as described below.

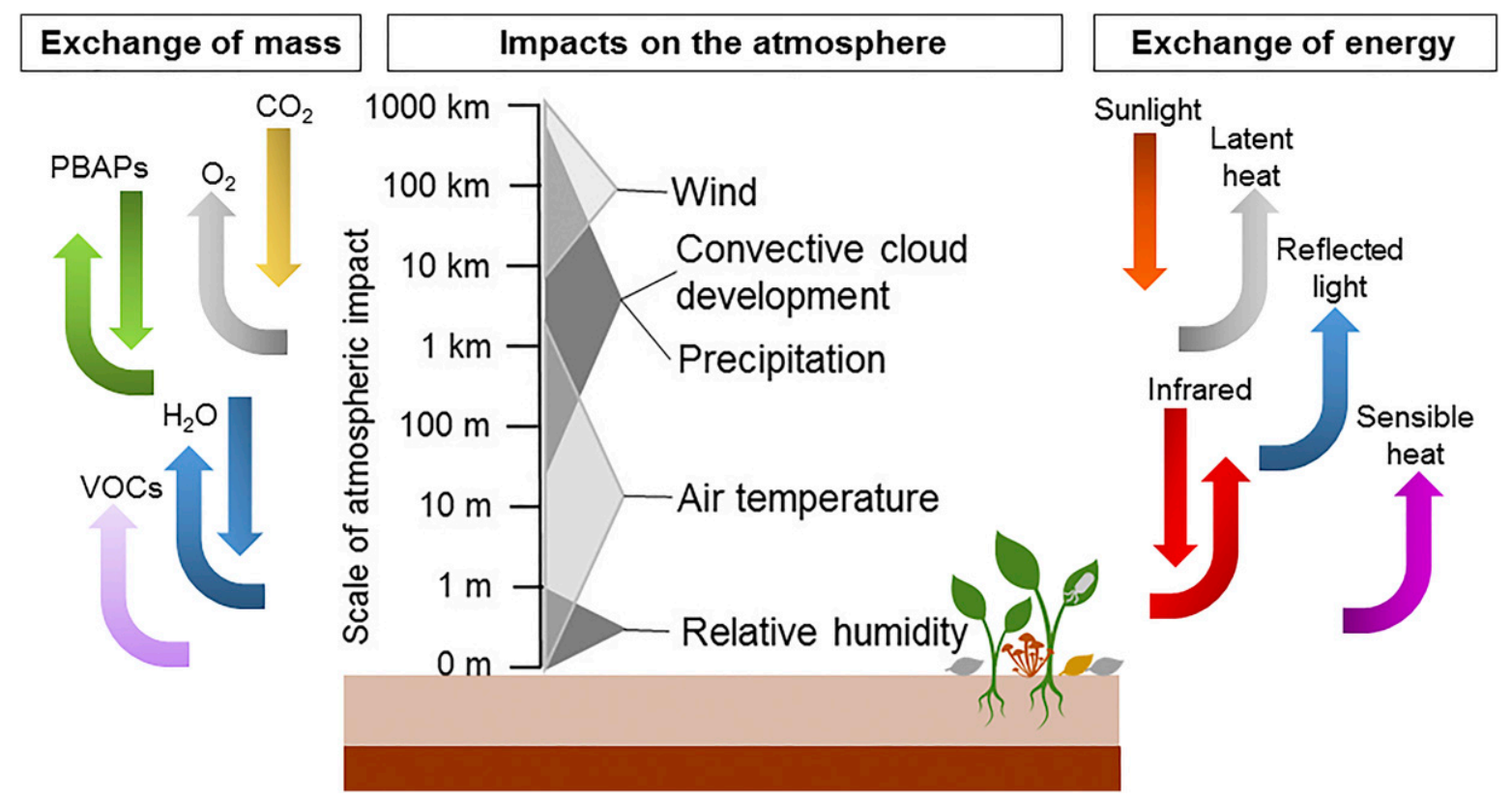

Fig. 1. Feedbacks between the atmosphere and plants with their associated microflora result from the exchange of mass (including gases, water, volatile organic compounds [VOCs], and primary biological aerosol particles [PBAPs]) and the exchange of energy. These exchanges have an impact on humidity, temperature, cloud cover, precipitation, and wind movement at a range of scales from microscale $\left(10^{-2}\right.$ to $\left.10^{3} \mathrm{~m}\right)$, to local scale $\left(10^{2}\right.$ to $\left.5 \times 10^{4} \mathrm{~m}\right)$, to meso-scale $\left(10^{4}\right.$ to $\left.2 \times 10^{5} \mathrm{~m}\right)$, and to macro-scale $\left(10^{5}\right.$ to $\left.10^{8} \mathrm{~m}\right)$. The extent to which vegetation impacts the exchanges of mass and energy depends on the climatic and geographical context and the type and health of the vegetation. In general, bare soil would reflect more light (i.e., have a higher albedo), would absorb little $\mathrm{CO}_{2}$, would release little $\mathrm{O}_{2}$ and few PBAPs. It would not release latent heat via evapotranspiration but would contribute to elevated temperatures due to exchange of sensible heat and infrared compared with vegetated land. Soil microflora can produce VOCs, but there would be a lower quantity and different chemical diversity released from bare soil than from vegetation. 


\section{TEMPERATURE}

Plant canopies have a marked influence on the albedo and rates of evapotranspiration associated with a given land surface due to the extent to which they absorb light, the total leaf area index, the depth of root systems relative to sources of water, and rates of photosynthesis. All these parameters vary among plant species and according to plant health. High albedo contributes to planetary cooling through the reflection of incoming light and lower accumulation of infrared radiation by the soil. Evapotranspiration also contributes to local cooling through the loss of latent heat. Subsequent cloud formation from evapotranspirated water vapor can increase cloud cover. Clouds then contribute to increasing planetary albedo but can also be a sort of insulating blanket that prevents heat loss. Changes in albedo and evapotranspiration interact competitively when increases in cooling due to evapotranspiration are outweighed by warming because of the decreases in albedo that accompany increased greening of land surfaces. The outcomes for temperature depend on geographic context as described below. The effects on surface temperature can be visualized with thermal scanning, for example (Hesslerová et al. 2013).

Deforestation and other forms of denuding of land surfaces markedly change albedo and the potential for evapotranspiration and thereby demonstrate the role of land cover on surface temperature. Research to assess the extent to which this has contributed to global warming has revealed the importance of geographic context on the effects of deforestation. In tropical regions, deforestation has contributed to the warming of mean temperature trends by about $0.3^{\circ} \mathrm{C}$ per decade. In stark contrast, deforestation of boreal forests has led to an overall cooling effect of over $0.5^{\circ} \mathrm{C}$ per decade in northern latitudes ( $\mathrm{Li}$ et al. 2016). Deforestation generally increases albedo. In northern latitudes, the cooling effect of intact forests is greater than that due to evapotranspiration and carbon sequestering via photosynthesis. Hence, it has been estimated that since about 1750 northern and midlatitude agricultural regions have cooled by about 1 to $2^{\circ} \mathrm{C}$ in winter and spring due to deforestation as the result of a loss of heat energy of about $2 \mathrm{Wm}^{-2}$ locally in Europe, China, and India (Betts et al. 2007). The amount of cooling from deforestation in northern and midlatitudes is on the same scale as the impacts of ozone, $\mathrm{N}_{2} \mathrm{O}$, halocarbons, and anthropogenic aerosols on the energy budget of the atmosphere (Betts et al. 2007). In contrast, in tropical forests, the cooling effect of evapotranspiration and of the increased local albedo due to cloud cover associated with forests offsets the warming effect from low albedo of forest canopies. This explains why deforestation in tropical regions is associated with climate warming and it provides critical information for reforestation/ afforestation efforts whose goal is to contribute to planetary cooling (Mahmood et al. 2014). Fragmentation of forests can also alter local temperature. In Wisconsin, fragmentation of forests that created large amounts of forest edge and increased distances between forest patches had colder minimum and average daily temperatures throughout the winter compared with less fragmented forests. Differences in temperatures between fragmented and less fragmented forests that were within $50 \mathrm{~km}$ of each other were much lower than expected. Surprisingly, they were equivalent to the temperature differences observed across a 650-km latitudinal gradient (Latimer and Zuckerberg 2017).

Replacement of forests by other types of plant cover can have significant effects on local temperatures even if the replacement cover has abundant foliage and active photosynthesis. The expansion of oil palm and other cash crops has led to massive deforestation particularly in Indonesia. Regions of Sumatra have seen their forested areas decrease from $93 \%$ (in 1977) to $38 \%$ (in 2009) of land cover due to the development of oil palm plantations and other cash crops (Sabajo et al. 2017). Differences in land surface temperatures between Sumatran forests and clear-cut areas can be as high as $10^{\circ} \mathrm{C}$. The average gain in surface temperature in regions of Sumatra with intense cultivation of cash crops relative to forested regions was about $6^{\circ} \mathrm{C}$ for young oil palm plantations, $2^{\circ} \mathrm{C}$ for forest plantations of fast-growing acacia and $1^{\circ} \mathrm{C}$ for mature oil palm plantations (Sabajo et al. 2017). In the effort to intensify oil palm production, plant scientists are calling for interdisciplinary approaches to adapt oil palm — via breeding, expansion of production regions and the use of integrated pest management practices - to the environmental consequences of climate change to assure the highest yields possible (Rival 2017)). Strikingly, this effort to enhance oil palm production seems to ignore the effects of oil palm on local climate and takes into account only how the crop is subjected to environmental conditions. There is an absence of vision about any of the possible modifications of the bio-physical nature of the crop and the plantation that could leverage environmental conditions. As is well-known, local ambient conditions of crops facilitate or restrain the life cycles of pests, pathogens, and their antagonists. For example, temperature is a key factor for insect life cycles such as weevils (Rhynchophorus ferrugineus) that are major pests of palm oil. Temperature significantly influences the fecundity and longevity of this pest of oil palm (Peng et al. 2016). Temperature also has an overriding influence on the rate of infection of rhinoceros beetles (Oryctes rhinoceros), another important pest of various palms, with viruses, entomofungal pathogens, and bacterial pathogens that could regulate beetle populations (Gopal et al. 2002). Agronomic practices could be used to modulate local temperature at the crop level to restrain pest development and to favor infection by natural antagonists. The impact of pests and pathogens on plant density and leaf area, for example, could also be considered from the point of view of a feedback between the oil palm plantation, the whole of the phytobiome and the abiotic conditions at local and regional scales.

\section{BOX 1}

\section{Glossary of terms}

- Albedo: The proportion of incident light that is reflected by a surface. Snow has a relatively high albedo of 50 to $70 \%$, whereas the albedo of oceans is about $6 \%$.

- Sensible heat: The heat required for a change in the temperature of a gas or an object with no change in phase. This is the heat that we feel.

- Latent heat: The heat needed to change the phase of matter (from solid to liquid to vapor) without a change in temperature. It is also referred to as the latent heat of fusion. It is the energy that is released into the environment during condensation of water vapor to liquid and during the freezing of water. 
WINDS, VAPOR TRANSPORT, AND THE POTENTIAL FOR RAIN AND SNOWFALL

The exchange of sensible heat and IR between land surfaces and the atmosphere contributes to the creation of temperature gradients in the atmosphere that drive various atmospheric processes including the generation of winds. However, recent findings show that there is also a major role for condensation of atmospheric water vapor in creating forces that drive winds. This brings to light a previously unsuspected role of plants in the maintenance of winds and of atmospheric water transport. The Ideal Gas Law that reigns our understanding of the behavior of gases indicates that, for a given volume of gas, its pressure is proportional to its temperature and the number of gas molecules in the volume. When moist air rises and cools, the number of water molecules in the gas phase of a given volume of air decreases as they condense. Recent research (Makarieva and Gorshkov 2007; Makarieva et al. 2013) has revealed that the reducing number of water molecules from the gas phase has a significant impact on air pressure-an effect that had not been previously evaluated from a theoretical viewpoint on the global and regional scales. This marked influence on pressure can build up over vegetation where there is sustained evapotranspiration creating a sort of pump that has been called the Biotic Pump.

The Biotic Pump concept explains how coastal forests contribute to winds through the creation of low pressure regions that draw in moist air from the oceans as a consequence of evapotranspiration and subsequent condensation of water vapor in the atmosphere. The resulting prevailing winds are capable of carrying moisture that sustains rainfall farther inland (Makarieva et al. 2013). The implication of the Biotic Pump concept is that without sufficient evapotranspiration along coastlines, winds that bring atmospheric moisture far inland across continents would be diminished (Ellison et al. 2017). The Biotic Pump concept thus explains that abrupt transitions from a wet to a dry climate can be dependent on the functioning of plants-whereas these abrupt transitions are poorly explained by the effect of latent heat (Boos and Storelvmo 2016). The Biotic Pump concept has focused on forests, but it can be scaled to other types of vegetated land cover depending on their force of evapotranspiration.

As winds travel they pick up atmospheric moisture and transport it from one location to other locations downwind. Transported atmospheric moisture is essential for cloud and rain formation over inland regions. At least $40 \%$ of rain that falls over land originates from water vapor that is emitted by evapotranspiration and transported via the atmosphere. Rain can fall directly on vegetation. But it is important to consider that precipitation contributes to down-stream watersheds. Hence, changes in rainfall patterns can have vast effects depending on the watershed dimensions. For regions under the influence of the Amazon forest, for example, up to $70 \%$ of rainfall arises from evapotranspirated water vapor (van der Ent et al. 2010). Accordingly, changes in land cover that alter the amount of water emitted into the atmosphere may have marked effects on rainfall over much larger scales than that of the land cover change. For example, modeling has shown that tropical deforestation may reduce rainfall by up to $2.5 \mathrm{~mm} \mathrm{day}^{-1}$ over regions that are distant to the sites of deforestation (Snyder et al. 2004). In Australia for example, logging between 1960 and 1980 removed about $50 \%$ of coastal forests south of Perth and coincided with a $16 \%$ decrease in rainfall about $100 \mathrm{~km}$ inland in the wheat belt region (Andrich and Imberger 2013). This highlights the important interdependencies among regions in terms of water vapor and rainfall. In addition to the other interdependencies in Australia and the Amazon indicated above, pioneering research has revealed that $80 \%$ of China's water resources originate from moisture that evaporates from the Eurasian continent, and that rainfall in the Congo basin depends on evaporation from East Africa and in turn is the source of water for rainfall in the Sahel (van der Ent et al. 2010). The extent of this interdependency can have significant political dimensions. Some nations, due to their geographic context, are completely dependent on others for the water vapor that creates their precipitation (Dirmeyer et al. 2009).

\section{AEROSOLS AND THE FATE OF CLOUDS}

Clouds are an assemblage of tiny droplets formed from water vapor that has condensed into the liquid phase onto aerosol particles called cloud condensation nuclei (CCN). Cloud formation therefore depends on the presence of water vapor and $\mathrm{CCN}$ in the atmosphere and the forces to uplift these to altitudes where temperature conditions permit condensation. While $\mathrm{CCN}$ are always present everywhere, their concentrations and sizes govern those of the resulting droplets of the cloud, thereby controlling cloud properties such as rain, graupel and hail, reflection of sunlight, and cloud expansiveness. Thermal uplifting and topographical features (mountains, for example) are the main forces that set the stage for cloud formation. Clouds are of major significance for phytobiomes because they can bring rainfall either directly to plants and/or bring snow and rain to higher elevations in water sheds that are sources of irrigation water. For the moisture circulating in the atmosphere from evapotranspiration, $57 \%$ of it returns as precipitation over land (van der Ent et al. 2010) where it moistens the ground and can initiate another cycle of evapotranspiration afresh if there is vegetation. Alternatively, this precipitation can feed into sources of surface and ground water that are eventually used for irrigation. Clouds not only reflect light (leading to cooling via increased albedo), they can also act as blankets by preventing heat loss by absorbing thermal infrared radiation and partially re-emitting it down to warm the surface. For example, in autumn and spring their presence can prevent radiative cooling that could otherwise lead to frost on nights with open skies. By mediating cloud formation, phytobiomes influence the subsequent heat blanketing and light reflection that clouds impart.

The effect of land use on cloud formation is strikingly apparent along the borders of the $3000 \mathrm{~km}$ State Barrier Fence of Western Australia (also known as the State Vermin Fence) constructed in the early 1900s to keep agricultural pests out of Western Australia. Along the $750 \mathrm{~km}$ southwestern-most section of the fence, native vegetation was eliminated on the western side for farming leading to marked changes in surface albedo, surface roughness and latent and sensible heat fluxes (McAlpine et al. 2009). The concomitant effect on cloud formation is distinctly apparent in satellite images where clouds are generally east of the anthropomorphic disturbances contained by the fence (Nair et al. 2011). This is a spectacular example because of the juxtaposition of large swathes of altered and native landscapes. Massive expanses of monocultures elsewhere in the world are likely to have had similar effects on surface properties, but without the same spectacular setting their effects are not so outrightly apparent.

Land cover influences not only where clouds form but also their fate. In the last decade there has been growing interest in the influence of aerosols emitted from plants-composed mostly of microorganisms but also of organic volatiles and pollen-on the outcome of cloud processes that lead to the formation of rain and snow. Aerosols control the average concentrations and sizes of cloud-particles and crystals that influence their coagulation into masses of water that are heavy enough to fall-a step essential for precipitation. For the majority of rainfall over continents and over midlatitude oceans and continents, rain falls mostly from clouds that contain ice (Mülmenstädt et al. 2015). If the cloud-base is cold (e.g., near $0^{\circ} \mathrm{C}$ ), so as to prevent coalescence, then aggregation of ice crystals can dominate the precipitation. At temperatures warmer 
than about $-38^{\circ} \mathrm{C}$ (the spontaneous freezing temperature of water, depending on drop size) (Atkinson et al. 2016), freezing requires catalysts - called ice nuclei-that are generally solid particles. Most plant pathologists are well aware of the ice catalyzing ability (ice nucleation activity) of the plant-associated bacterium Pseudomonas syringae. Discovered in the 1970s, the efficiency of the ice nucleation activity of this bacterium is not surpassed by any other naturally occurring material found in the atmosphere (Murray et al. 2012). Furthermore, only the ice catalyzing particles of biological origin (bio-INPs), from microorganisms such as $P$. syringae, the rust fungi (Morris et al. 2013) and other soil- and plant-associated microorganisms (Després et al. 2012; Fröhlich-Nowoisky et al. 2015) can catalyze ice formation at relatively warm subzero temperatures (warmer than $-10^{\circ} \mathrm{C}$ ). Therefore, these bio-INP aerosols are increasingly thought to be a limiting factor for rainfall or snowfall in situations where cloud-top temperatures are too warm for dust or other mineral particles to initiate ice formation and where cloud-base temperatures are too cold for the warm rain process (coalescence of droplets) to prevail (Morris et al. 2014).

The bio-INPs emitted from plants are thought to set into place a Bioprecipitation cycle (Morris et al. 2014). In this cycle, rainfall enhances the growth of plants and their associated microflora. In turn, there is increased evapotranspiration and emission of bio-INPs and other aerosols into the atmosphere that influence the outcome of subsequent cloud processes involved in precipitation. The existence of this cycle is corroborated by a growing list of observations. Ice nucleation active microorganisms such as $P$. syringae, rusts, Fusarium spp., etc. are emitted from plants and are part of the net upward flux of microorganisms into the atmosphere (Lighthart and Shaffer 1994; Lindemann et al. 1982) where they have been detected at cloud heights and beyond (Amato et al. 2017; Sands et al. 1982; Stakman and Christensen 1946). Under natural conditions, INPs that are active at relatively warm temperatures $\left(>-10^{\circ} \mathrm{C}\right)$, including bio-INPs, fall out of clouds at warmer temperatures than do the INPs active at colder temperatures (Stopelli et al. 2015; Stopelli et al. 2017; Stopelli et al. 2016). This was demonstrated by collecting snow from clouds as they rose up a mountain top, by determining the abundance of the INPs active at different temperatures in the falling snow and by assessing the precipitation history of the cloud according to the ratio of the $\mathrm{O}^{16}$ and $\mathrm{O}^{18}$ isotopes in the snow (Stopelli et al. 2015). The early loss of the INPs active at warm temperatures from clouds is expected if they have a role in precipitation. This fall-out contributes to their deposition earlier rather than later in the life span of a cloud and influence dissemination patterns of microbial INPs. Furthermore, precipitation and moisture in general are clearly favorable for microbial growth. But interestingly, the momentum of heavy rainfalls favors a flush of growth of $P$. syringae, in particular, shortly after the rainfall - a flush that can persist for several days to weeks (Hirano et al. 1996). Atmospheric physicists have also observed that at the onset of rainfall, and for up to several weeks afterward, there is an increase in the atmospheric content of INPs and of the abundance of biological particles in general in the air (Bigg et al. 2015; Huffman et al. 2013; Prenni et al. 2013). These INPs constitute the aerosols that are then transported upwards into the atmosphere for yet another feedback cycle.

The feedback of rainfall on subsequent rainfall over the past century has been mapped (http://w3.avignon.inra.fr/rainfallfeedback/ index.html). It appears to have specific geographic and seasonal patterns that are coherent with the suspected roles that topography and seasonal changes in aerosol sources have on the outcome of cloud processes (Morris et al. 2017). The key role of potential plant pathogens in the Bioprecipitation cycle begs the question of how to balance the benefits and disadvantages of these microorganisms for plant health (Morris et al. 2016) and it creates exciting opportunities for research to resolve this dilemma. For example, could crops be created and strategically deployed for their capacity to emit bioINPs as an ecosystem service rather than for their production of plant tissues to be harvested? Alternatively, could we manage disease caused by plant pathogens that were also bio-INPs to generate sufficient aerosols to impact cloud processes without causing crop loss of economic importance? Research in this regard could begin by identifying the bio-INPs and the plant hosts that would be best adapted to such strategies.

\section{PHYTOBIOMES AS AN INTEGRAL PART OF LAND-ATMOSPHERE FEEDBACK CYCLES}

It is becoming increasingly difficult to dissociate climate and weather extremes from land use change and intensification in the current Anthropocene (Monastersky 2015). In Australia, where industrial development started relatively late, the convergence of recurrent droughts and the rapid expansion of intensive agriculture has led to concern that continued disregard for the role of land surface feedbacks in current and future droughts will be catastrophic for the environment, economy and society (McAlpine et al. 2009). This has stimulated initiatives to integrate knowledge of land-atmosphere feedbacks into the management of vegetation and into woodland and forest restoration (Syktus and McAlpine 2016) and to develop social justice frameworks to assure equity in water access among stakeholders all while assuring sustainability and environmental protection (Lukasiewicz et al. 2013). These initiatives can have largescale consequences because rainfall and water availability are vital for flood forecasting and management of urban drainage; for filling catchments essential for aquatic wildlife, drinking and irrigation water, and electricity generation; and for the planting and harvesting

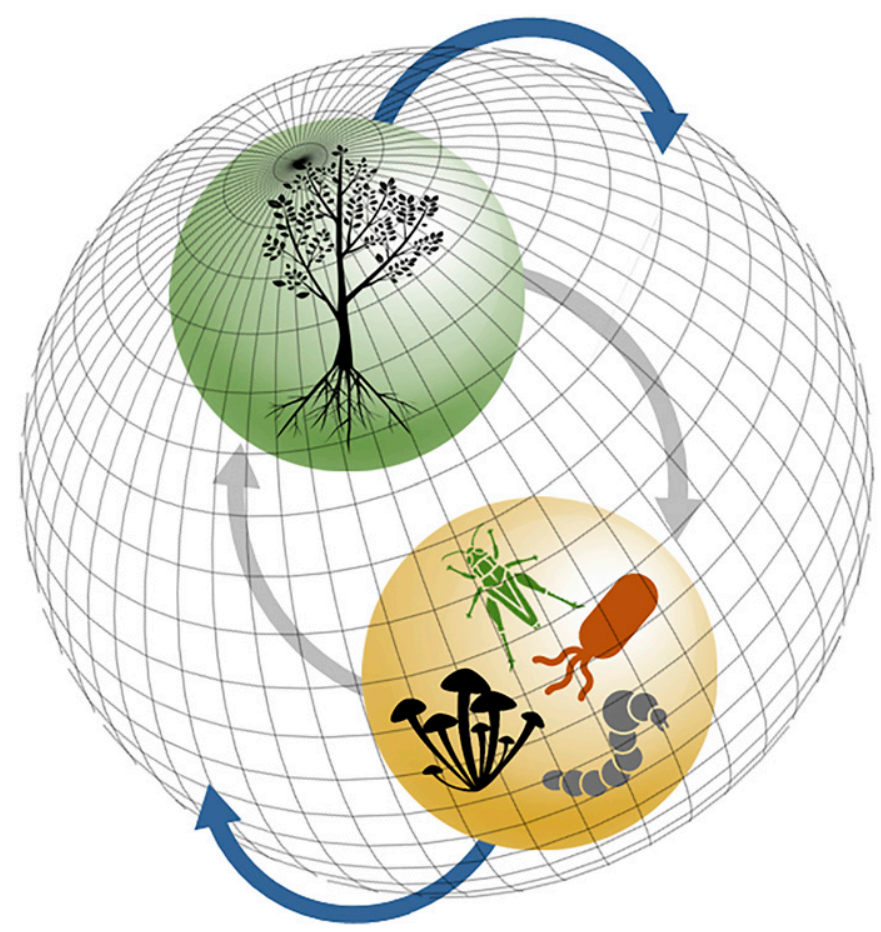

Fig. 2. Interactions between plants and their associated biota occur in an environmental context that, itself, can be modified by plants, microorganisms, and other biota. The scope of phytobiomes can be defined in the context of the Earth system where plants and their associated biota are actors in defining local and regional environmental conditions in addition to being subjected to them. 
of crops. There is an opportunity to start to integrate the full scope of phytobiomes-including the ensemble of their biological components and their effects on soil properties, root proliferation and plant physiology, for example, as well as the inherent traits and behaviors of the plant itself-into land-atmosphere feedback models.

Uncertainties about and extreme variability of climate and weather are destabilizing for agricultural production. Climatedriven economic downturns resulting from agroecological catastrophes have historically been at the root of large-scale human crises (Zhang et al. 2011) and will likely continue to influence global economy (Carleton and Hsiang 2016). In light of the various ways by which vegetated land cover and its associated microorganisms can influence surface temperature, winds, clouds, and precipitation, phytobiomes have the potential to actively modulate local and regional climate, and to mitigate climate change. Therefore, to effectively tackle the grand challenges in plant production and food security, phytobiomes need to be explored at regional scales as well as at farm, plant and microscopic scales. It will be particularly important to elucidate the upscaling of biotic/abiotic interactions at the microscopic and plant levels to regional levels. Such upscaling is exemplified by the large-scale impacts on precipitation that arise from the much smaller scale details of the ecology of bio-INPs such as $P$. syringae on plant surfaces (Vacher et al. 2016). Phytobiomes should be set in the context of Earth systems science, linking the natural and physical sciences to social sciences (Lappalainen et al. 2016) to assess yield not only in terms of plant products but also in terms of impacts on processes of the physical environment (Fig. 2). Hence, managing phytobiomes for plant health can be part of a more comprehensive strategy of managing phytobiomes for an ensemble of their ecosystem services.

\section{ACKNOWLEDGMENTS}

The numerous discussions that I have had over the past decade with participants in the BioIceAtmos network and with co-authors of Ellison et al. (2017) contributed greatly to my understanding of many of the concepts presented in this paper. I also thank V. Phillips, Lund University, Sweden, for his input to assure that the information in the text concerning physics was accurate; D. Sheil, A. Makarieva, and V. Gorshkov (authors of the Biotic Pump concept) for their help in clearly explaining this concept; and F. Fabre, INRA-Bordeaux, France, for providing useful input on the clarity of the content of the manuscript.

\section{LITERATURE CITED}

Amato, P., Joly, M., Besaury, L., Oudart, A., Taib, N., Moné, A. I., Deguillaume, L., Delort, A.-M., and Debroas, D. 2017. Active microorganisms thrive among extremely diverse communities in cloud water. PLoS One 12:e0182869.

Andrich, M. A., and Imberger, J. 2013. The effect of land clearing on rainfall and fresh water resources in Western Australia: A multi-functional sustainability analysis. Int. J. Sustain. Dev. World Ecol. 20:549-563.

Atkinson, J. D., Murray, B. J., and O'Sullivan, D. 2016. Rate of homogenous nucleation of ice in supercooled water. J. Phys. Chem. A 120:6513-6520.

Betts, R. A., Falloon, P. D., Goldewijk, K. K., and Ramankutty, N. 2007. Biogeophysical effects of land use on climate: Model simulations of radiative forcing and large-scale temperature change. Agric. For. Meteorol. 142: 216-233.

Bigg, E. K., Soubeyrand, S., and Morris, C. E. 2015. Persistent after-effects of heavy rain on concentrations of ice nuclei and rainfall suggest a biological cause. Atmos. Chem. Phys. 15:2313-2326.

Boos, W. R., and Storelvmo, T. 2016. Near-linear response of mean monsoon strength to a broad range of radiative forcings. Proc. Nat. Acad. Sci. 113: 1510-1515.
Bright, R. M., Zhao, K., Jackson, R. B., and Cherubini, F. 2015. Quantifying surface albedo and other direct biogeophysical climate forcings of forestry activities. Glob. Change Biol. 21:3246-3266.

Carleton, T. A., and Hsiang, S. M. 2016. Social and economic impacts of climate. Science 353:aad9837.

Després, V. R., Huffman, J. A., Burrows, S. M., Hoose, C., Safatov, A. S., Buryak, G., Fröhlich-Nowoisky, J., Elbert, W., Andreae, M. O., Pöschl, U., and Jaenicke, R. 2012. Primary biological aerosol particles in the atmosphere: A review. Tellus B 64:015598. doi.org/10.11263402/tellusb. v64i0.15598

Dirmeyer, P. A., Brubaker, K. L., and DelSole, T. 2009. Import and export of atmospheric water vapor between nations. J. Hydrol. (Amst.) 365:11-22.

Ellis, E. C., Klein Goldewijk, K., Siebert, S., Lightman, D., and Ramankutty, N. 2010. Anthropogenic transformation of the biomes, 1700 to 2000. Glob. Ecol. Biogeogr. 19:589-606.

Ellison, D., Morris, C. E., Locatelli, B., Sheil, D., Cohen, J. M., Murdiyarso, D., Gutierrez, V., van Noordwijk, M., Creed, I. F., Pokorny, J., Gaveau, D., Spracklen, D. V., Tobella, A. B., Ilstedt, U., Teuling, A. J., Gebrehiwot, S. G., Sands, D. C., Muys, B., Verbist, B., Springgay, E., Sugandi, Y., and Sullivan, C. A. 2017. Trees, forests and water: Cool insights for a hot world. Glob. Environ. Change 43:51-61.

Faye, E., Rebaudo, F., Yánez-Cajo, D., Cauvy-Fraunié, S., and Dangles, O. 2016. A toolbox for studying thermal heterogeneity across spatial scales: From unmanned aerial vehicle imagery to landscape metrics. Methods Ecol. Evol. 7:437-446.

Fröhlich-Nowoisky, J., Hill, T. C. J., Pummer, B. G., Yordanova, P., Franc, G. D., and Pöschl, U. 2015. Ice nucleation activity in the widespread soil fungus Mortierella alpina. Biogeosciences 12:1057-1071.

Gopal, M., Gupta, A., Sathiamma, B., and Nair, C. P. R. 2002. Microbial pathogens of the coconut pest Oryctes rhinoceros: Influence of weather factors on their infectivity and study of their coincidental ecology in Kerala, India. World J. Microbiol. Biotechnol. 18:417-421.

Hesslerová, P., Pokorný, J., Brom, J., and Rejšková-Procházková, A. 2013. Daily dynamics of radiation surface temperature of different land cover types in a temperate cultural landscape: Consequences for the local climate. Ecol. Eng. 54:145-154.

Hirano, S. S., Baker, L. S., and Upper, C. D. 1996. Raindrop momentum triggers growth of leaf-associated populations of Pseudomonas syringae on fieldgrown snap bean plants. Appl. Environ. Microbiol. 62:2560-2566.

Huffman, J. A., Prenni, A. J., DeMott, P. J., Pöhlker, C., Mason, R. H., Robinson, N. H., Fröhlich-Nowoisky, J., Tobo, Y., Després, V. R., Garcia, E., Gochis, D. J., Harris, E., Müller-Germann, I., Ruzene, C., Schmer, B., Sinha, B., Day, D. A., Andreae, M. O., Jiminez, J. L., Gallagher, M., Kreidenweis, S. M., Bertram, A. K., and Pöschl, U. 2013. High concentrations of biological aerosol particles and ice nuclei during and after rain. Atmos. Chem. Phys. 13: 6151-6164.

Lappalainen, H. K., Kerminen, V. M., Petäjä, T., Kurten, T., Baklanov, A., Shvidenko, A., Bäck, J., Vihma, T., Alekseychik, P., Andreae, M. O., Arnold, S. R., Arshinov, M., Asmi, E., Belan, B., Bobylev, L., Chalov, S., Cheng, Y., Chubarova, N., De Leeuw, G., Ding, A., Dobrolyubov, S., Dubtsov, S., Dyukarev, E., Elansky, N., Eleftheriadis, K., Esau, I., Filatov, N., Flint, M., Fu, C., Glezer, O., Gliko, A., Heimann, M., Holtslag, A. A. M., Hõrrak, U., Janhunen, J., Juhola, S., Järvi, L., Järvinen, H., Kanukhina, Konstantinov, P., Kotlyakov, V., Kieloaho, A. J., Komarov, A. S., Kujansuu, J., Kukkonen, I., Duplissy, E. M., Laaksonen, A., Laurila, T., Lihavainen, H., Lisitzin, A., Mahura, A., Makshtas, A., Mareev, E., Mazon, S., Matishov, D., Melnikov, V., Mikhailov, E., Moisseev, D., Nigmatulin, R., Noe, S. M., Ojala, A., Pihlatie, M., Popovicheva, O., Pumpanen, J., Regerand, T., Repina, I., Shcherbinin, A., Shevchenko, V., Sipilä, M., Skorokhod, A., Spracklen, D. V., Su, H., Subetto, D. A., Sun, J., Terzhevik, A. Y., Timofeyev, Y., Troitskaya, Y., Tynkkynen, V. P., Kharuk, V. I., Zaytseva, N., Zhang, J., Viisanen, Y., Vesala, T., Hari, P., Christen Hansson, H., Matvienko, G. G., Kasimov, N. S., Guo, H., Bondur, V., Zilitinkevich, S., and Kulmala, M. 2016. Pan-Eurasian Experiment (PEEX): Towards a holistic understanding of the feedbacks and interactions in the land-atmosphere-ocean-society continuum in the northern Eurasian region. Atmos. Chem. Phys. 16: 14421-14461.

Latimer, C. E., and Zuckerberg, B. 2017. Forest fragmentation alters winter microclimates and microrefugia in human-modified landscapes. Ecography 40:158-170.

Li, Y., Zhao, M., Mildrexler, D. J., Motesharrei, S., Mu, Q., Kalnay, E., Zhao, F., Li, S., and Wang, K. 2016. Potential and actual impacts of deforestation and afforestation on land surface temperature. J. Geophys. Res. Atmos. 121: $14,372-14,386$. 
Lighthart, B., and Shaffer, B. T. 1994. Bacterial flux from chaparral into the atmosphere in mid-summer at a high desert location. Atmos. Sci. 28: 1267-1274.

Lindemann, J., Constantinidiou, H. A., Barchet, W. R., and Upper, C. D. 1982. Plants as source of airbone bacteria, including ice nucleation-active bacteria. Appl. Environ. Microbiol. 44:1059-1063.

Lukasiewicz, A., Syme, G. J., Bowmer, K. H., and Davidson, P. 2013. Is the environment getting its fair share? An analysis of the Australian water reform process using a social justice framework. Soc. Justice Res. 26:231-252.

Mahmood, R., Pielke, R. A., Hubbard, K. G., Niyogi, D., Dirmeyer, P. A., McAlpine, C. A., Carleton, A. M., Hale, R., Gameda, S., Beltrán-Przekurat, A., Baker, B., McNider, R., Legates, D. R., Shepherd, M., Du, J., Blanken, P. D., Frauenfeld, O. W., Nair, U. S., and Fall, S. 2014. Land cover changes and their biogeophysical effects on climate. Int. J. Climatol. 34:929-953.

Makarieva, A. M., and Gorshkov, V. G. 2007. Biotic pump of atmospheric moisture as driver of the hydrological cycle on land. Hydrol. Earth Syst. Sci. 11:1013-1033.

Makarieva, A. M., Gorshkov, V. G., Sheil, D., Nobre, A. D., and Li, B.-L. 2013. Where do winds come from? A new theory on how water vapor condensation influences atmospheric pressure and dynamics. Atmos. Chem. Phys. 13:1039-1056.

McAlpine, C. A., Syktus, J., Ryan, J. G., Deo, R. C., McKeon, G. M., McGowan, H. A., and Phinn, S. R. 2009. A continent under stress: Interactions, feedbacks and risks associated with impact of modified land cover on Australia's climate. Glob. Change Biol. 15:2206-2223.

Monastersky, R. 2015. Anthropocene: The human age. Nature 519:144-147.

Morris, C. E., Barny, M. A., Berge, O., Kinkel, L., and Lacroix, C. 2016. Frontiers for research on the ecology of plant pathogenic bacteria: Fundamentals for sustainability. Mol. Plant Pathol. 18:308-319.

Morris, C. E., Conen, F., Huffman, J. A., Phillips, V., Poeschl, U., and Sands, D. C. 2014. Bioprecipitation: A feedback cycle linking Earth history, ecosystem dynamics and land use through biological ice nucleators in the atmosphere. Glob. Change Biol. 20:341-351.

Morris, C. E., Sands, D. C., Glaux, C., Samsatly, J., Asaad, S., Moukahel, A. R., Gonçalves, F. L. T., and Bigg, E. K. 2013. Urediospores of rust fungi are ice nucleation active at $>-10^{\circ} \mathrm{C}$ and harbor ice nucleation active bacteria. Atmos. Chem. Phys. 13:4223-4233.

Morris, C. E., Soubeyrand, S., Bigg, E. K., Creamean, J. M., and Sands, D. C. 2017. Mapping rainfall feedback to reveal the potential sensitivity of precipitation to biological aerosols. Bull. Am. Meteor. Soc. 98:1109-1118.

Mülmenstädt, J., Sourdeval, O., Delanoë, J., and Quaas, J. 2015. Frequency of occurrence of rain from liquid-, mixed-, and ice-phase clouds derived from ATrain satellite retrievals. Geophys. Res. Letts. 42(15):2015GL064604.

Murray, B. J., O’Sullivan, D., Atkinson, J. D., and Webb, M. E. 2012. Ice nucleation by particles immersed in supercooled cloud droplets. Chem. Soc. Rev. 41:6519-6554.

Nair, U. S., Y. Wu, J. Kala, T. J. Lyons, R. A. Pielke, and J. M. Hacker. 2011. The role of land use change on the development and evolution of the west coast trough, convective clouds, and precipitation in southwest Australia. J. Geophys. Res. Atmos. 116:D07103.

Oke, T. R. 1987. Boundary Layer Climates. Routledge, Oxford.

Peng, L., Miao, Y., and Hou, Y. 2016. Demographic comparison and population projection of Rhynchophorus ferrugineus (Coleoptera: Curculionidae) reared on sugarcane at different temperatures. Sci. Rep. 6:31659.

Prenni, A. J., Tobo, Y., Garcia, E., DeMott, P. J., Huffman, J. A., McCluskey, C. S., Kreidenweis, S. M., Prenni, J. E., Pöhlker, C., and Pöschl, U. 2013. The impact of rain on ice nuclei populations at a forested site in Colorado. Geophys. Res. Lett. 40:227-231.

Rival, A. 2017. Breeding the oil palm (Elaeis guineensis Jacq.) for climate change. OCL 24:D107.

Sabajo, C. R., le Maire, G., June, T., Meijide, A., Roupsard, O., and Knohl, A. 2017. Expansion of oil palm and other cash crops causes an increase of the land surface temperature in the Jambi province in Indonesia. Biogeosciences 14:4619-4635.

Sands, D. C., Langhans, V. E., Scharen, A. L., and de Smet, G. 1982. The association between bacteria and rain and possible resultant meteorological implications. J. Hung. Meteorol. Serv. 86:148-152.

Snyder, P. K., Delire, C., and Foley, J. A. 2004. Evaluating the influence of different vegetation biomes on the global climate. Clim. Dyn. 23:279-302.

Stakman, E., and Christensen, C. M. 1946. Aerobiology in relation to plant disease. Bot. Rev. 12:205-253.

Stopelli, E., Conen, F., Guilbaud, C., Zopfi, J., Alewell, C., and Morris, C. E. 2017. Ice nucleators, bacterial cells and Pseudomonas syringae in precipitation at Jungfraujoch. Biogeosciences 14:1189-1196.

Stopelli, E., Conen, F., Morris, C. E., Hermann, E., Bukowiecki, N., and Alewell, C. 2015. Ice nucleation active particles are efficiently removed by precipitating clouds. Sci. Rep. 5:16433.

Stopelli, E., Conen, F., Morris, C. E., Herrmann, E., Henne, S., Steinbacher, M., and Alewell, C. 2016. Predicting abundance and variability of ice nucleating particles in precipitation at the high-altitude observatory Jungfraujoch. Atmos. Chem. Phys. 16:8341-8351.

Syktus, J. I., and McAlpine, C. A. 2016. More than carbon sequestration: Biophysical climate benefits of restored savanna woodlands. Sci. Rep. 6:29194.

Tivoli, B., Andrivon, D., Baranger, A., Calonnec, A., and Jeger, M. J. 2013. Foreword: Plant and canopy architecture impact on disease epidemiology and pest development. Eur. J. Plant Pathol. 135:453-454.

Vacher, C., Hampe, A., Porté, A. J., Sauer, U., Compant, S., and Morris, C. E. 2016. The phyllosphere: Microbial jungle at the plant-climate interface. Annu. Rev. Ecol. Evol. Syst. 47:1-24.

van der Ent, R. J., Savenije, H. H. G., Schaefli, B., and Steele-Dunne, S. C. 2010. Origin and fate of atmospheric moisture over continents. Water Resour. Res. 46:W09525.

Zhang, D. D., Lee, H. F., Wang, C., Li, B., Pei, Q., Zhang, J., and An, Y. 2011. The causality analysis of climate change and large-scale human crisis. Proc. Nat. Acad. Sci. 108:17296-17301. 